\title{
Receptor-Type Tyrosine-Protein Phosphatase R
}

National Cancer Institute

\section{Source}

National Cancer Institute. Receptor-Type Tyrosine-Protein Phosphatase R. NCI

Thesaurus. Code C37314.

Receptor-type tyrosine-protein phosphatase $\mathrm{R}(657 \mathrm{aa}, \sim 74 \mathrm{kDa}$ ) is encoded by the human PTPRR gene. This protein is involved in both protein dephosphorylation and the sequestration of unphosphorylated mitogen-activated protein kinases. 